\title{
ANALISIS PENGAKUAN PENDAPATAN DAN BEBAN PADA CV. RESTU IBU BANJARMASIN
}

\author{
Yuli Fitriyani \\ Dosen Akuntansi, Politeknik Negeri Tanah Laut \\ J1. A. Yani Km. 6 Ds. Panggung Kec. Pelaihari Kab. Tanah Laut, Kalimantan Selatan \\ E-mail : yulihazami@gmail.com
}

\begin{abstract}
Abstrak
CV RESTU IBU Banjarmasin adalah sebuah perusahaan yang bergerak dalam bidang pertambangan dan perdagangan batu bara. Selama ini, perusahaan CV. RESTU IBU Banjarmasin menggunakan Cash Basis dimana hal tersebut belum sesuai dengan Standar Akuntansi Keuangan. Maka dari itu perlu diterapkan suatu pengakuan pendapatan dan beban berdasarkan Accrual Basis. Kerangka pemikiran dalam penelitian ini adalah menguatkan penerapan pengakuan terhadap pendapatan yang diperoleh dan beban yang dikeluarkan oleh perusahaan, kemudian metode pencatatan pendapatan dan beban tersebut serta penyajiannya dalam suatu laporan keuangan yang tepat dan sesuai dengan Standar Akuntansi Keuangan. Berdasarkan kelemahan pada Cash Basis maka penulis menyarankan sebaiknya menggunakan dasar Accrual Basis. Dengan demikian perusahaan dapat mengetahui dengan pasti berapa besarnya pendapatan yang diakui dan yang dibebankan oleh perusahaan tersebut.
\end{abstract}

Kata Kunci : Pendapatan dan beban, Cash Basis dan Accrual Basis

\section{PENDAHULUAN}

Sekarang ini bangsa Indonesia sedang mengalami krisis ekonomi dimana harga barang dan juga BBM melambung tinggi. Namun kita masih mampu bertahan, terbukti masih banyaknya perusahaanperusahaan yang bermunculan baik berupa usaha industri, pertanian, peternakan, perdagangan maupun usaha lainnya.

Pulau Kalimantan khususnya Kalimantan Selatan banyak terdapat lahan atau pegunungan yang luas membentang, yang di dalamnya terdapat bermacammacam material yang bermanfaat bagi lingkungan dan masyarakat luas. Materialmaterial yang terdapat di dalam tan ah terdapat pula bahan material batu bara yang dapat digunakan sebagai bahan bakar kereta api, bahan bakar yang digunakan di pabrik-pabrik, dan lain sebagainya.

Maka dari itu banyak bermunculan perusahaan-perusahaan yang bergerak di bidang pertambangan salah satunya adalah CV. RESTU IBU Banjarmasin yang bergerak dalam bidang perdagangan dan penjualan batu bara baik yang sudah berbentuk bongkahan kecil maupun besar, batu yang berbentuk bongkahan besar di creser kemudian dijual kepada pihak luar baik di daerah sendiri maupun diluar daerah. Pihak manajemen perusahaan tentunya berusaha agar bagaimana perusahaan bisa mendapatkan keuntungan yang semaksimal mungkin, yang tentunya berkaitan erat hubungannya dengan masalah pengakuan pendapatan perusahaan yang tentu merupakan tujuan dari semua perusahaan pada umumnya.

Selama ini, pengakuan pendapatan dan beban pada CV. RESTU IBU dalam praktiknya menggunakan dasar kas dimana dalam mengakuinya pendapatannya, perusahaan hanya mengakui pada saat barang telah dibayar oleh pihak konsumen (pada saat kas diterima) sehingga pendapatan yang diakui perusahaan nilainya terlalu rendah dan hal ini dapat berakibat laba yang disajikan juga terlalu rendah sehingga usaha tersebut akan kelihatan kurang berhasil dibandingkan dengan kenyataan sebenarnya.

Pada setiap akhir periode akuntansi, perusahaan CV. RESTU IBU juga tidak 
mengakui adanya utang gaji karyawan, utang listrik, air dan keperluan kantor. Hal ini menyebabkan nilai beban gaji karyawan, beban listrik, air dan keperluan kantor yang disajikan juga terlalu rendah.

Prinsip Accrual Basis artinya pengakuan berdasarkan waktu terjadinya suatu perkiraan, sehingga pada akhir periode akuntansi perlu adanya identifikasi terhadap perubahan-perubahan posisi dalam suatu nilai nominal.

\section{PERUMUSAN MASALAH}

Permasalahan yang ada pada CV. Restu Ibu Banjarmasin yaitu dimana pendapatan dan bebannya masih menggunakan metode Cash Basis sebagai berikut :

1. CV. RESTU IBU Banjarmasin dalam mengakui pendapatannya hanya pada saat perusahaan telah menerima pembayaran dari pihak pemberi kontrak

2. Perusahaan tidak mengakui adanya utang terhadap beban-beban berupa beban gaji, beban listrik, air dan beban keperluan kantor.

\section{BATASAN MASALAH}

Dalam penelitian ini penulis membatasi masalahnya hanya pada pengakuan pendapatan dan beban dengan menggunakan metode Accrual Basis.

\section{TUJUAN PENELITIAN}

Adapun tujuan yang ingin dicapai penulis dalam penelitian ini adalah untuk mencoba menerapkan suatu pengakuan pendapatan dan juga beban berdasarkan Accrual Basis.

\section{MANFAAT PENELITIAN}

Hasil penelitian ini dimanfaatkan sebagai bahan bacaan bagi pembaca untuk lebih mengetahui bagaimana sistem pengakuan pendapatan dan beban yang benar dengan menggunakan metode Accrual Basis.

\section{LANDASAN TEORI}

\section{Konsep Dasar Dan Prinsip Akuntansi Yang Mendasari Pengakuan Pendapatan Dan Beban}

Konsep Dasar menurut (Zaki Baridwan, 2009) yang mendasari penyusunan prinsip akuntansi adalah prinsip biaya historis (historical cost principle), prinsip mempertemukan (matching principle), prinsip pengakuan pendapatan (revenue recognition principle), prinsip konsistensi (consistency principle) dan prinsip lengkap (full disclousure).

Menurut (Charles T. Horngren et.al, 1997) prinsip dasar akuntansi yang mendasari pengakuan pendapatan adalah prinsip umum yang memandu kapan pendapatan dicatat menyatakan bahwa pendapatan dicatat pada saat terjadinya dan tidak sebelumnya. Pada sebagian besar kasus, pendapatan diakui pada saat perusahaan telah mengirimkan barang atau jasa kepada pelanggan.

Menurut (Kusnadi, 1983) dalam bukunya yang berjudul "Teori Akuntansi" mengatakan bahwa pada umumnya, pengakuan pendapatan yang banyak dilakukan orang (perusahaan) adalah sebagai berikut :

1. Cash Basis (Dasar Penerimaan uang)

Konsep ini mengakui suatu pendapatan pada saat uang itu diterima dan mengakui biaya pada saat uang tersebut dikeluarkan.

2. Accrual Basis (Dasar Akrual)

Di dalam asumsi dasar akrual, penerapan akuntansi keuangan di dasarkan tidak tunai (akrual) artinya transaksi diakui pada saat terjadinya tanpa dikaitkan dengan transaksi kas. 
Menurut (Henry Simamora, 2000) gambar dibawah ini memperlihatkan komparasi pengakuan pendapatan dan beban menurut dasar kas dan dasar akrual.

\begin{tabular}{|l|l|l|}
\hline & $\begin{array}{l}\text { Akuntansi } \\
\text { Dasar Kas }\end{array}$ & $\begin{array}{l}\text { Akuntansi } \\
\text { Dasar Akrual }\end{array}$ \\
\hline $\begin{array}{l}\text { Pendapatan } \\
\text { diakui }\end{array}$ & $\begin{array}{l}\text { Pada saat } \\
\text { kas } \\
\text { diterima }\end{array}$ & $\begin{array}{l}\text { Pada saat } \\
\text { diperoleh } \\
\text { (barang } \\
\text { diserahkan } \\
\text { atau jasa } \\
\text { dilakukan) }\end{array}$ \\
\hline $\begin{array}{l}\text { Beban } \\
\text { diakui }\end{array}$ & $\begin{array}{l}\text { Pada saat } \\
\text { kas } \\
\text { dibayar }\end{array}$ & $\begin{array}{l}\text { Pada saat } \\
\text { dikeluarkan } \\
\text { untuk } \\
\text { menghasilkan } \\
\text { pendapatan }\end{array}$ \\
\hline
\end{tabular}

\section{PENDAPATAN}

Menurut (Zaki Baridwan, 1992) "Pendapatan adalah aliran masuk aktiva yang timbul dari penyerahan barang dagangan atau jasa atau aktivitas usaha lainnya dalam suatu periode. Istilah pendapatan dalam prinsip ini merupakan istilah yang luas, dimana di dalamnya termasuk juga pendapatan bunga, sewa dan laba penjualan aktiva dan lain-lain".

\section{Beban}

Menurut (Charles T. Horngren, 1997) bahwa beban merupakan penurunan dalam ekuitas pemilik yang timbul dari penyampaian barang dan jasa pada langganan. Beban merupakan biaya perusahaan dalam menjalankan operasinya dan merupakan kebalikan dari pendapatan. Contoh dari beban antara lain sewa kantor, gaji pegawai, iklan koran, pembayaran untuk listrik, air, gas dan lain sebagainya.

\section{METODE PENELITIAN}

Penelitian ini menggunakan model penelitian data kuantitatif yaitu data yang didasarkan pada nilai absolute atau nilai relative misalnya dinyatakan dalam jumlah rupiah dan presentasi perhitungan berupa data-data keuangan seperti neraca dan laporan rugi laba.

\section{HASIL PENELITIAN DAN PEMBAHASAN}

\section{HASIL PENELITIAN}

\section{Sejarah Singkat Perusahaan}

Sejak tahun 2001 berdirilah sebuah perusahaan yang bergerak dalam bidang pertambangan dan perdagangan batu bara yang diberi nama CV. RESTU IBU Banjarmasin.

Perusahaan ini bukan satu-satunya perusahaan pertambangan dan perdagangan batu bara di Kalimantan Selatan. Hal ini dikarenakan pulau Kalimantan adalah pulau yang kaya akan hasil tambangnya. Dan CV. RESTU IBU didirikan karena pendirinya melihat bahwa menggeluti bidang pertambangan dan perdagangan batu bara mempunyai prospek yang bagus.

Setelah cukup lama perusahaan ini berdiri dan perkembangannya dniliaicukup baik, maka didirikanlah sebuah kantor tetap di Jalan Simpang Gusti Komplek R.E. Junaidi RT.14 No. 43 Banjarmasin Provinsi Kalimantan Selatan.

Pada tahun itu pula tepatnya pada tanggal 24 Juni 2001 dengan SIUP Eksplorasi No. 545.2.014/PU/DPE/2002. Dan izin penjualan No. 545./99.USTA/DISTAM, CV. RESTU IBU didirikan oleh Bapak Mochammad Sairoji. 


\section{Struktur Organisasi}

Fungsi struktur organisasi dalam perusahaan sangat penting guna mempertegas kedudukan, wewenang dan tanggung jawab masing-masing fungsi guna memperlancar proses pelaksanaan perintah dalam suatu organisasi. Struktur organisasi ini juga memperjelas uraian kerja dalam perusahaan.

Setiap perusahaan baik besar maupun kecil tentu memerlukan suatu struktur organisasi yang sesuai dengan jenjang pengawasan masing-masing untuk mencapai tujuan yang ingin dicapai. Semakin besar suatu perusahaan, maka akan semakin komplek masalah yang dihadapi perusahan tersebut, sehingga perusahaan semacam itu memerlukan struktur organisasi yang lebih rapi dan terencana.

Sedangkan perusahaan menengah kebawah pada umumnya memiliki struktur yang lebih sederhana, karena ruang lingkup usahanya tidak terlalu luas dan penangannya tidak memerlukan karyawan yang terlalu banyak namun ada pemisahan tugas untuk masing-masing karyawannya.

CV. RESTU IBU dalam melaksanakan operasi perusahaan hingga saat ini, telah dapat dilihat tenaga kerja sebanyak 36 (tiga puluh enam) orang. Untuk lebih jelasnya dapat dilihat pada tabel dibawah ini :

\begin{tabular}{|l|l|c|}
\hline No. & \multicolumn{1}{|c|}{ Keterangan } & $\begin{array}{c}\text { Jumlah } \\
\text { Tenaga } \\
\text { Kerja }\end{array}$ \\
\hline 1. & Direktur & 1 \\
2. & Manager & 1 \\
3. & Operasional dan & 2 \\
4. & Administrasi d & 3 \\
5. & Keuangan & 3 \\
6. & Bagian Tambang & 3 \\
\hline
\end{tabular}

\begin{tabular}{l|l|l|}
\hline 7. & Bagian Alat Berat & 4 \\
8. & Bagian Trading & 1 \\
9. & Bagian Stock Pile & 6 \\
10. & Bagian Pengupahan & 4 \\
11 & Operator & 3 \\
& Mekanik & \\
& Keamanan & 36 \\
\hline \multicolumn{2}{|c|}{ Jumlah } \\
\multicolumn{2}{|c|}{ Sumber : $C V . \quad$ RESTU } \\
Banjarmasin
\end{tabular}

\section{PEMBAHASAN HASIL PENELITIAN}

Berdasarkan data-data penelitian yang diperoleh mengenai pengakuan pendapatan dan beban pada CV. RESTU IBU Banjarmasin.

\section{RESTU IBU Pendapatan Hasil Kontrak Batu bara}

\begin{tabular}{|l|c|}
\hline \multicolumn{1}{|c|}{ Keterangan } & \multicolumn{1}{|c|}{ Jumlah } \\
\hline $\begin{array}{l}\text { Pendapatan dari } \\
\text { hasil kontrak } \\
\text { pengadaan batu } \\
\text { bara }\left(^{*}\right)\end{array}$ & Rp. 152.500.000,- \\
\hline
\end{tabular}

Keterangan $(*)$ :

Perjanjian kontrak yang dilakukan oleh CV. RESTU IBU Banjarmasin dengan CV. MAKMUR BERSAMA yaitu tentang pengadaan batu bara. Dimana kontrak pengadaan batu bara ini sebesar Rp. 345.000.000,- yang ditanda tangani pada tanggal 3 November 2007 dan berakhir pada tanggal 12 April 2008, akan tetapi perusahaan hanya dapat menyelesaikan sebagian kontrak tersebut hingga sampai tanggal 31 Desember 2007 adalah sebesar Rp.152.500.000,-. Karena perusahaan menggunakan pencatatan dengan metode Cash Basis maka oleh perusahaan nilai sebesar Rp. 152.500.000,- ini belum diakui sebagai pendapatan karena belum diterimanya pembayaran dari $\mathrm{CV}$. MAKMUR BERSAMA. Sedangkan jika menggunakan dasar Accrual Basis, nilai 
tersebut sudah diakui sebagai pendapatan di tahun 2007.

\section{RESTU IBU \\ BEBAN YANG MASIH HARUS DITANGGUN PERUSAHAAN (BEBAN TERHUTANG)}

\begin{tabular}{|c|l|l|}
\hline No & \multicolumn{1}{|c|}{ Keterangan } & \multicolumn{1}{|c|}{ Jumlah } \\
\hline 1 & Beban Gaji & $\begin{array}{l}\text { Rp. 23. } \\
345.000,-*\end{array}$ \\
\hline 2 & $\begin{array}{l}\text { Beban Listrik dan } \\
\text { air }\end{array}$ & $\begin{array}{l}\text { Rp. } \\
875.000,-*\end{array}$ \\
\hline 3 & $\begin{array}{l}\text { Beban keperluan } \\
\text { Kantor }\end{array}$ & $\begin{array}{l}\text { Rp. } \\
1.250 .000,-*\end{array}$ \\
\hline & Total Beban & $\begin{array}{l}\text { Rp. } \\
25.470 .000,-*\end{array}$ \\
\hline
\end{tabular}

Istilah beban terhutang disini merujuk pada suatu kewajiban yang berasal dari beban yang telah diakui atau telah terjadi dalam perusahaan tapi belum bayar.

Keterangan $(*)$ :

1. Beban Gaji yang masih harus dibayar sebesar Rp. 23.345.000,-

Berdasarkan hasil survey yang penulis lakukan, beban tersebut terjadi dikarenakan dalam membayar gaji karyawannya perusahaan melakukan pembayaran gaji setiap tanggal 1 (satu) tiap awal bulan.

Hingga pada saat akhir periode akuntansi yaitu 31 Desember 2007, masih terdapat satu bulan yang harus ditanggung perusahaan yaitu pertanggal 1 Desember 2007 - 1 Januari 2008 sebesar Rp. 23.345.000,- karena menurut perhitungan dari tanggal 1 Januari 2007 - 1 Desember 2007 hanya terdapat 11 (sebelas) bulan artinya belum genap 12 bulan (satu periode akuntansi).

2. Beban Listrik dan air

Begitu juga beban listrik dan air, beban tersebut ada dikarenakan perusahaan belum melunasi pembayaran untuk bulan Desember 2007, karena perusahaan baru membayarnya di awal bulan Januari 2008 yaitu sebesar Rp. 875.000,-.

3. Beban Keperluan Kantor

Pada Awal bulan Desember 2007, Perusahaan CV. RESTU IBU Banjarmasin membeli Alat Tulis Kantor (ATK) sebesar Rp. 3.525.000,-. Pembayaran tersebut dilakukan secara angsuran, dimana perusahaan harus membayar sebelum tanggal jatuh tempo yaitu tanggal 30 Desember 2007. Akan tetapi sampai tanggal jatuh tempo tersebut, pihak perusahaan belum melunasi seluruhnya. Hanya sebesar Rp. 2.275.000,- yang baru dilunasi oleh CV. RESTU IBU, sisa yang belum dilunasi oleh CV. RESTU IBU Banjarmasin yaitu RP. 3.525.000,- dikurangi Rp. 2.275.000,- adalah sebesar Rp. $1.250 .000,-$.

\section{ANALISIS TERHADAP PENGAKUAN PENDAPATAN}

Sebagaimana yang telah dikemukakan sebelumnya, CV. RESTU IBU Banjarmasin dalam pengakuan pendapatan masih menggunakan dasar kas (cash basis), dimana pendapatan dicatat sewaktu diterimanya uang secara tunai. Hal ini mengakibatkan semua pendapatan yang diperoleh selama tahun berjalan yang diterima oleh CV. RESTU IBU menjadi tidak benar karena terdapat pendapatan yang harus diterima di tahun 2007 sehingga pendapatan tahun berjalan tersebut akan terlihat lebih rendah. Hal ini akan terus berlanjut untuk periode-periode berikutnya, akibatnya laporan keuangan yang 
dihasilkan juga akan menyajikan suatu informasi yang tidak andal.

Berdasarkan hal tersebut penggunaan dasar cash basis dalam pengakuan pendapatan CV. RESTU IBU tidak sesuai dengan teori yang mendasari prinsip dan konsep dasar akuntansi serta tidak sesuai dengan ketentuan yang berlaku, untuk itu perlu dilakukan koreksi dengan menggunakan dasar accrual basis, dimana pendapatan diakui dan dilaporkan sesuai dengan periode berjalan.

\section{ANALISIS TERHADAP PENGAKUAN BEBAN}

Adapun analisis pembahasan beban pada CV. RESTU IBU Banjarmasin pada dasarnya juga masih terdapat beban-beban yang diakui dengan dasar cash basis, akuntansi dasar kas dianggap lemah karena akuntansi ini terfokus pada aktivitasaktivitas penerimaan atau pembayaran kas yang sebenarnya mempunyai imbas ekonomi kecil dan dapat dengan mudah dimanipulasi. Misalnya, tatkala perusahaan membeli barang atau jasa, saat pembayaran atau pembelian tersebut tentunya tergantung pada kebijakan perusahaan. Jika sebuah perusahaan membeli barang pada penghujung tahun, perusahaan bisa saja menunda pencatatan pembelian tersebut dengan sekedar menunggu hingga permulaan periode berikutnya untuk mengeluarkan cek atas pembelian. Dengan menunda pengeluaran hingga periode berikutnya, maka manajemen akan mampu memberikan kesan telah berhasil mengurangi defisit ekonomi.

Pengaruh atas akuntansi dasar kas tersebut akan semakin kentara manakala pembayaran kas dimaksudkan untuk menuai masa manfaat selama beberapa periode akuntansi. Dengan melihat hal itu, maka penulis mencoba merubah akuntansi dasar kas yang dimiliki oleh CV. RESTU
IBU menjadi dasar akrual karena dasar akrual tersebut tidak hanya memberikan transaksi-transaksi dimasa lalu yang melibatkan penerimaan dan pembayran kas saja, tetapi juga kewajiban pembayaran kas dimasa depan serta sumber daya yang menunjukkan kas yang akan diterima dimasa yang akan datang.

Pengakuan pendapatan sangat erat kaitannya dengan beban, berdasarkan prinsip matching, harus ada pengaitan antara pendapatan yang diakui dengan pengeluaran beban untuk memperoleh pendapatan tersebut, sehingga informasi yang disajikan merupakan informasi yang andal dan sesuai dengan ketentuan yang berlaku.

\section{KESIMPULAN}

Adapun kesimpulan yang dapat penulis sampaikan atas pembahasan yang telah penulis lakukan adalah :

1. CV. RESTU IBU Banjarmasin didirikan pada tahun 2001 dan bergerak pada bidang perdagangan batu bara. CV. RESTU IBU Banjarmasin memiliki sebuah kantor tetap di Jalan Simpang Gusti Komplek R.E Junaidi RT. 14 No. 43 Banjarmasin propinsi Kalimantan Selatan dan pada tahun itu pula tepatnya pada tanggal 24 Juni 2001 dengan SIUP Eksplorasi No. 545.2.014/PU/DPE/2002. Dan izin Penjualan No. 545./99.USTA/DISTAM, CV RESTU IBU didirikan oleh Bapak Mochammad Sairoji.

2. Masalah yang dihadapi oleh CV. RESTU IBU Banjarmasin adalah di dalam mengakui pendapatan dan beban, perusahaan mengakui berdasarkan cash basis hal itu menyebabkan perusahaan belum menerapkan sistem akuntansi yang 
tepat dan belum sesuai dengan Standar Akuntansi Keuangan.

3. CV. RESTU IBU Banjarmasin sebaiknya dalam mencatat pendapatan yang diterima berdasarkan kontrak dan beban yang masih harus dibayar menggunakan mentode Accrual basis sehingga pendapatan dan beban yang diakui pada tahun tersebut sesuai dengan kenyataan.

\section{DAFTAR PUSTAKA}

Baridwan, Zaki. 1992. Intermediate Accounting. Edisi Ketujuh. Penerbit BPFE. Yogyakarta.

Horngren, Harrison. 1997. Akuntansi di Indonesia. Salemba Empat. Jakarta.

Ikatan Akuntansi Indonesia. 2002. Standar Akuntansi Keuangan. Salemba Empat. Jakarta.

Kusnadi. 1983. Teori Akuntansi. Universitas Brawijaya. Malang.

Simamora, Henry. 2000. Akuntansi Basis Pengambilan Keputusan Bisnis. Jilid I. Salemba Empat. Jakarta. 